\title{
Rapid Normalization of High Glutamic Acid Decarboxylase Autoantibody Titers and Preserved Endogenous Insulin Secretion in a Patient with Diabetes Mellitus: A Case Report and Literature Review
}

\author{
Nobumasa Ohara ${ }^{1,2}$, Masanori Kaneko ${ }^{1,2}$, Tatsuo Furukawa ${ }^{3}$, Tadashi Koike ${ }^{3}$, Hirohito Sone ${ }^{2}$, \\ Shoichiro Tanaka ${ }^{4}$, Kenzo Kaneko ${ }^{1}$ and Kyuzi Kamoi ${ }^{5}$
}

\begin{abstract}
A 59-year-old Japanese woman developed diabetes mellitus without ketoacidosis in the presence of glutamic acid decarboxylase autoantibody (GADA) $(24.7 \mathrm{U} / \mathrm{mL})$. After the amelioration of her hyperglycemia, the patient had a relatively preserved serum C-peptide level. Her endogenous insulin secretion capacity remained almost unchanged during 5 years of insulin therapy. The patient's GADA titers normalized within 15 months. The islet-related autoantibodies, including GADA, are believed to be produced following the autoimmune destruction of pancreatic beta cells and are predictive markers of type 1 diabetes mellitus. Therefore, the transient appearance of GADA in our patient may have reflected pancreatic autoimmune processes that terminated without progression to insulin deficiency.
\end{abstract}

Key words: diabetes mellitus, glutamic acid decarboxylase autoantibody, C-peptide, human leukocyte antigen, insulin therapy

(Intern Med 55: 485-489, 2016)

(DOI: 10.2169/internalmedicine.55.5398)

\section{Introduction}

Diabetes mellitus is a group of metabolic diseases that are characterized by chronic hyperglycemia due to insufficient insulin action $(1,2)$. Type 1 diabetes mellitus (T1D) is caused by insulin deficiency resulting from the destruction of pancreatic beta cells. It is considered an organ-specific autoimmune disease. The islet-related autoantibodies, which are believed to be produced following the autoimmune destruction of pancreatic beta cells, are used as a predictive or diagnostic marker of T1D (3). The major autoantibodies in clinical use include islet cell antibody (ICA), insulinomaassociated antigen 2 (IA-2) antibody, zinc transporter-8 (ZnT8) antibody, insulin autoantibody (IAA), and glutamic acid decarboxylase autoantibody (GADA). They typically disappear over time after the disappearance of beta cells.

There are a few reported cases of diabetes mellitus that are characterized by the rapid disappearance of GADA, despite the preservation of insulin secretion capacity $(4,5)$. We herein report the case of a patient who developed diabetes mellitus in the presence of transient GADA and remained in an insulin-independent state for 5 years.

\section{Case Report}

A 59-year-old woman was admitted to our hospital at the beginning of June 2009 because of hyperglycemia. The patient had never been obese and had a history of putamen hemorrhage, which occurred at 50 years of age, at which point she started medical treatment with felodipine $(5 \mathrm{mg}$ per day) and pravastatin (10 mg per day) for essential hy-

\footnotetext{
${ }^{1}$ Department of Endocrinology and Metabolism, Nagaoka Red Cross Hospital, Japan, ${ }^{2}$ Department of Hematology, Endocrinology and Metabolism, Niigata University Faculty of Medicine, Japan, ${ }^{3}$ Department of Hematology, Nagaoka Red Cross Hospital, Japan, ${ }^{4}$ Third Department of Internal Medicine, Interdisciplinary Graduate School of Medicine and Engineering, University of Yamanashi, Japan and ${ }^{5}$ Center of Diabetes, Endocrinology and Metabolism, Joetsu General Hospital, Japan
}

Received for publication March 19, 2015; Accepted for publication June 8, 2015

Correspondence to Dr. Nobumasa Ohara, oharan@med.niigata-u.ac.jp 
Table 1. Laboratory Findings on the Second Day of Admission, June 2009.

\begin{tabular}{|c|c|c|}
\hline \multicolumn{3}{|l|}{ Hematology } \\
\hline Red blood cells & $511 \times 10^{4} / \mu \mathrm{L}$ & $(427-571)$ \\
\hline Hemoglobin & $15.8 \mathrm{~g} / \mathrm{dL}$ & $(12.4-17.2)$ \\
\hline Hematocrit & $45.9 \%$ & $(38.7-50.3)$ \\
\hline White blood cells & $4,000 / \mu \mathrm{L}$ & $(4,000-9,000)$ \\
\hline Platelets & $20.7 \times 10^{4} / \mu \mathrm{L}$ & $(12.0-30.0)$ \\
\hline \multicolumn{3}{|l|}{ Chemistry } \\
\hline Fasting plasma glucose & $12.7 \mathrm{mmol} / \mathrm{L}$ & $(3.9-6.1)$ \\
\hline Fasting serum C-peptide & $1.4 \mathrm{ng} / \mathrm{mL}$ & $(1.1-3.3)$ \\
\hline Fasting serum immunoreactive insulin & $5.5 \mu \mathrm{U} / \mathrm{mL}$ & $(2.2-12.4)$ \\
\hline HbA1c (NGSP) & $12.4 \%$ & $(4.6-6.2)$ \\
\hline Total protein & $7.2 \mathrm{~g} / \mathrm{dL}$ & $(6.7-8.3)$ \\
\hline Albumin & $4.3 \mathrm{~g} / \mathrm{dL}$ & $(3.8-5.3)$ \\
\hline Total cholesterol & $121 \mathrm{mg} / \mathrm{dL}$ & $(130-220)$ \\
\hline Triglycerides & $76 \mathrm{mg} / \mathrm{dL}$ & $(50-150)$ \\
\hline Aspartate aminotransferase & $23 \mathrm{IU} / \mathrm{L}$ & $(13-33)$ \\
\hline Alanine aminotransferase & $30 \mathrm{IU} / \mathrm{L}$ & $(8-42)$ \\
\hline Amylase & $47 \mathrm{IU} / \mathrm{L}$ & $(43-118)$ \\
\hline Urea nitrogen & $9.2 \mathrm{mg} / \mathrm{dL}$ & $(8.0-20.0)$ \\
\hline Creatinine & $0.37 \mathrm{mg} / \mathrm{dL}$ & $(0.60-1.00)$ \\
\hline Sodium & $136 \mathrm{mmol} / \mathrm{L}$ & $(137-147)$ \\
\hline Potassium & $4.4 \mathrm{mmol} / \mathrm{L}$ & $(3.5-4.7)$ \\
\hline Chloride & $103 \mathrm{mmol} / \mathrm{L}$ & $(98-108)$ \\
\hline C-reactive protein & $0.05 \mathrm{mg} / \mathrm{dL}$ & $(<0.30)$ \\
\hline \multicolumn{3}{|l|}{ Urinalysis } \\
\hline Specific gravity & 1.045 & $(1.006-1.030)$ \\
\hline Glucose & $4+$ & $(-)$ \\
\hline Ketone bodies & - & $(-)$ \\
\hline Protein & - & $(-)$ \\
\hline Occult blood & - & $(-)$ \\
\hline
\end{tabular}

The reference range for each parameter is shown in parentheses.

NGSP: National Glycohemoglobin Standardization Program (6)

pertension and dyslipidemia. Her mother had a history of essential hypertension and cerebral infarction. The patient followed a traditional Japanese diet based on rice, had never smoked, and did not drink alcohol. A routine medical checkup conducted in December 2008 showed a body weight (BW) of $56 \mathrm{~kg}$ and a high-normal level of fasting plasma glucose $(5.9 \mathrm{mmol} / \mathrm{L}$; reference range, 3.9-6.1 $\mathrm{mmol} /$ L). She developed thirst and polyuria without prodromal symptoms, such as fever or infection, in April 2009. To quench her thirst, she consumed large amounts of Japanese tea and $0.35 \mathrm{~L}$ of orange juice per day. Six weeks later, she visited her primary care doctor, who noted a 6-kg decrease in her BW that had occurred in the month before her visit. She was found to have diabetes mellitus [casual plasma glucose, $27.8 \mathrm{mmol} / \mathrm{L}$; HbA1c National Glycohemoglobin Standardization Program (NGSP), 12.1\%; negative urinary ketone bodies]. She was instructed not to consume orange juice and was prescribed an $\alpha$-glucosidase inhibitor (150 mg of miglitol per day). Four days later, following a positive test for GADA (Cosmic Corporation, Tokyo, Japan) (24.1 $\mathrm{U} / \mathrm{mL}$; reference range, $<1.5 \mathrm{U} / \mathrm{mL}$ ), the patient was referred to our hospital (casual plasma glucose, $19.9 \mathrm{mmol} / \mathrm{L}$; negative urinary ketone bodies) and was admitted the next day.

Upon admission, the patient was alert. She was $154 \mathrm{~cm}$ tall and weighed $49 \mathrm{~kg}$ (body mass index, $20.7 \mathrm{~kg} / \mathrm{m}^{2}$ ). Her body temperature, blood pressure, and heart rate were 36.7 ${ }^{\circ} \mathrm{C}, 130 / 72 \mathrm{mmHg}$, and 77 beats per minute, respectively.
Her oral cavity was slightly dry, but a physical examination revealed no thyroid struma, chest rales, heart murmurs, abdominal tenderness, pretibial edema, joint swelling, or eruption. No paralysis, rigidity, or ataxia was detected and her Achilles' tendon reflex was normal. A blood chemistry analysis of blood samples obtained in the fasting state showed a plasma glucose level of $12.7 \mathrm{mmol} / \mathrm{L}$ and a serum C-peptide level of $1.4 \mathrm{ng} / \mathrm{mL}$. Urinalysis was negative for ketone bodies (Table 1). A chest X-ray showed no abnormalities in the lungs. Abdominal ultrasonography detected no abnormalities in the liver, spleen, pancreas, or kidneys.

The patient's plasma glucose levels before breakfast, lunch, dinner, and at bedtime on the second day after admission were $12.7,20.7,15.6$, and $12.2 \mathrm{mmol} / \mathrm{L}$, respectively, under treatment with a $1,400 \mathrm{kcal} /$ day diet. She tested positive for GADA (24.7 U/mL) (Cosmic Corporation), but tests for IA-2 antibody $(<0.4 \mathrm{U} / \mathrm{mL})$ and IAA $(<0.4 \mathrm{U} / \mathrm{mL})$ were negative. The patient's urinary C-peptide excretion $(43.9 \mu \mathrm{g} /$ day; reference range, $22.8-155.2 \mu \mathrm{g} /$ day) was relatively preserved. The patient started multiple insulin injection therapy with insulin aspart and insulin detemir to correct her hyperglycemia on day 3 after admission (at which time the administration of miglitol was discontinued). Her fasting plasma glucose fell to $6.2 \mathrm{mmol} / \mathrm{L}$ within 1 week of using injected insulin (total amount $20 \mathrm{U} / \mathrm{day}$ ). Thus, her insulin regimen was switched to biphasic insulin aspart 30 twice daily on day 12 after admission.

A meal load test performed on day 14 after admission showed a post-meal plasma glucose level of $15.5 \mathrm{mmol} / \mathrm{L}$ and a serum C-peptide level of $4.1 \mathrm{ng} / \mathrm{mL}$ (Table 2). The patient tested positive for rheumatoid factor $(50 \mathrm{IU} / \mathrm{mL}$; reference range, $<15 \mathrm{IU} / \mathrm{mL}$ ), but she had no characteristic findings of rheumatoid arthritis and tested negative for antinuclear antibody (titer <1:40), anti-cyclic citrullinated peptide antibody $(<0.6 \mathrm{U} / \mathrm{mL})$, and SS-A and SS-B antibodies. In addition, she tested negative for organ-specific autoantibodies, such as pituitary antibody, thyroid peroxidase antibody $(<0.3 \mathrm{U} / \mathrm{mL})$, thyroglobulin antibody $(<0.3 \mathrm{U} / \mathrm{mL})$, thyroid-stimulating hormone receptor antibody $(<1.0 \mathrm{U} / \mathrm{mL})$, gastric parietal cell antibody (titer $<1: 10$ ), intrinsic factor antibody, and the adrenal antibody (titer $<1: 10$ ). Human leukocyte antigen (HLA) typing showed the presence of $A * 24 / 33$, B*44/52, and $C^{*} 12: 02 / 14: 03$ class I genes and DRB1*09: 01/12:01, DQB1*03:03/(-), DQA1*03:02/(-), and DPB1*05: $01 /(-)$ class II genes. She was discharged on the 18th day of hospitalization after participating in a diabetes mellitus selfmanagement education program.

The patient continued insulin injections with biphasic insulin aspart 30 at the outpatient clinic of our hospital. Her GADA titers decreased and reached normal levels within 15 months (Table 2). Her post-meal plasma glucose and serum C-peptide levels were $12.7 \mathrm{mmol} / \mathrm{L}$ and $3.9 \mathrm{ng} / \mathrm{mL}$, respectively, at 6 months; and $18.6 \mathrm{mmol} / \mathrm{L}$ and $3.8 \mathrm{ng} / \mathrm{mL}$, respectively, at 5.6 years after the clinical onset of her diabetes. In January 2015, she tested negative for GADA, IA-2 antibodies, ZnT8 antibodies, ICA, and IAA. The test for 
Table 2. Serial Changes in the Clinical Parameters of Diabetes Mellitus.

\begin{tabular}{|c|c|c|c|c|c|}
\hline & $\begin{array}{c}\text { June } 2009 \\
\text { (day } 2 \text { of } \\
\text { admission) }\end{array}$ & $\begin{array}{r}\text { June } 2009 \\
\text { (day } 14 \text { of } \\
\text { admission) }\end{array}$ & $\begin{array}{c}\text { Dec } \\
2009\end{array}$ & $\begin{array}{l}\text { Sept } \\
2010\end{array}$ & $\begin{array}{c}\text { Jan } \\
2015\end{array}$ \\
\hline GADA $(\mathrm{U} / \mathrm{mL})[<1.5]$ & 24.7 & N.M. & 7.3 & $<1.3$ & $<1.3$ \\
\hline IA-2 antibody $(\mathrm{U} / \mathrm{mL})[<0.4]$ & $<0.4$ & N.M. & $<0.4$ & N.M. & $<0.4$ \\
\hline ZnT8 antibody $(\mathrm{U} / \mathrm{mL})[<15.0]$ & N.M. & N.M. & $<10.0$ & N.M. & $<10.0$ \\
\hline ICA (JDF units) $[<1.25]$ & N.M. & N.M. & N.M. & N.M. & $<1.25$ \\
\hline Insulin autoantibody $(\mathrm{U} / \mathrm{mL})[<0.4]$ & $<0.4$ & N.M. & $<0.4$ & N.M. & $<0.4$ \\
\hline Plasma glucose before breakfast $(\mathrm{mmol} / \mathrm{L})^{\mathrm{a}}$ & 12.7 & 6.9 & 7.4 & 5.7 & 8.4 \\
\hline Plasma glucose $2 \mathrm{~h}$ after breakfast $(\mathrm{mmol} / \mathrm{L})^{\mathrm{a}}$ & N.M. & 15.5 & 12.7 & N.M. & 18.6 \\
\hline Serum C-peptide before breakfast $(\mathrm{ng} / \mathrm{mL})^{\mathrm{a}}$ & 1.4 & 0.5 & 1.1 & N.M. & 1.1 \\
\hline Serum C-peptide $2 \mathrm{~h}$ after breakfast $(\mathrm{ng} / \mathrm{mL})^{\mathrm{a}}$ & N.M. & 4.1 & 3.9 & N.M. & 3.8 \\
\hline HbA1c (NGSP) (\%) & 12.4 & N.M. & 6.7 & 6.1 & 7.4 \\
\hline Body weight (kg) & 49 & 49 & 50 & 45 & 46 \\
\hline Amount of injected insulin (U/day) ${ }^{b}$ & 0 & 12 & 9 & 6 & 4 \\
\hline
\end{tabular}

The reference range of each islet-related autoantibody titer is shown in square brackets.

${ }^{\text {a In June }} 2009$ (day 14 of admission), Dec 2009, and Jan 2015, plasma glucose and serum C-peptide levels were measured both before and $2 \mathrm{~h}$ after the patient had ingested a 480 -kcal breakfast. The insulin injection was briefly discontinued on each morning of these 3 days.

${ }^{\mathrm{b}}$ The patient started insulin injection therapy on day 3 of admission in June 2009 and received injections of biphasic insulin aspart 30 (twice daily) beginning on day 12 of admission.

GADA: glutamic acid decarboxylase autoantibody, IA-2: insulinoma-associated antigen 2, ICA: islet cell antibody, NGSP: National Glycohemoglobin Standardization Program (6), N.M.: not measured, ZnT8: zinc transporter-8

Table 3. Summary of Reported Patients who Developed Diabetes Mellitus with Transient Positivity for Glutamic Acid Decarboxylase Autoantibodies and who Remained in an Insulin-independent State.

\begin{tabular}{|c|c|c|c|c|c|c|c|c|c|c|c|c|c|c|}
\hline \multirow[b]{2}{*}{ Case } & \multirow[b]{2}{*}{ Sex } & \multirow[b]{2}{*}{$\begin{array}{c}\text { Age } \\
\text { (years) }\end{array}$} & \multirow[b]{2}{*}{$\begin{array}{l}\text { HLA- HLA- } \\
\text { DRB1 DQB1 }\end{array}$} & \multirow{2}{*}{$\begin{array}{c}\text { Duration of } \\
\text { hyperglycemic } \\
\text { symptoms before } \\
\text { diabetes diagnosis }^{\mathrm{a}}\end{array}$} & \multicolumn{5}{|c|}{ Laboratory findings at time of diabetes diagnosis } & \multirow[b]{2}{*}{$\begin{array}{l}\text { Duration of } \\
\text { positivity for } \\
\text { GADA }\end{array}$} & \multirow[b]{2}{*}{$\begin{array}{c}\text { U-CPR } \\
\text { ( } \mu \mathrm{g} / \text { day) after } \\
\text { disappearance } \\
\text { of GADA }^{c}\end{array}$} & \multirow[b]{2}{*}{$\begin{array}{c}\text { Thyroid } \\
\text { autoantibodies }^{\mathrm{d}}\end{array}$} & \multirow[b]{2}{*}{ Other findings $^{\mathrm{e}}$} & \multirow[b]{2}{*}{ Ref. } \\
\hline & & & & & $\begin{array}{l}\text { Urinary } \\
\text { ketone } \\
\text { bodies }\end{array}$ & $\begin{array}{l}\text { Plasma } \\
\text { glucose } \\
(\mathrm{mmol} / \mathrm{L})\end{array}$ & $\begin{array}{c}\text { HbAlc } \\
\text { (NGSP) } \\
(\%)^{b}\end{array}$ & $\begin{array}{l}\mathrm{U}-\mathrm{CPR} \\
(\mu \mathrm{g} / \text { day })\end{array}$ & $\begin{array}{c}\text { GADA } \\
\text { titer } \\
(\mathrm{U} / \mathrm{mL})\end{array}$ & & & & & \\
\hline 1 & Female & 24 & $\begin{array}{cc}15: 02 & 06: 01 \\
/(-) & /(-)\end{array}$ & 1 year & $( \pm)$ & 15.3 & 13.8 & 4.2 & 3,854 & $<2$ years & $\begin{array}{c}36 \\
{[2 \text { years] }}\end{array}$ & $\begin{array}{l}\text { TPO-Ab: }(-) \\
\text { Tg-Ab: }(-) \\
\text { TR-Ab: N.M. }\end{array}$ & None & 4 \\
\hline 2 & Male & 72 & N/A N/A & 1 week & $(-)$ & 17.2 & 10.7 & 63 & 12.1 & $<10$ months & $\begin{array}{c}64 \\
{[2 \text { years] }}\end{array}$ & N.M. & $\begin{array}{l}\text { Positivity for ANA } \\
\text { and SS-A antibodies }\end{array}$ & 5 \\
\hline 3 & Female & 59 & $\begin{array}{l}09: 01 \quad 03: 03 \\
/ 12: 01 \quad /(-)\end{array}$ & 6 weeks & $(-)$ & 27.8 & 12.4 & $\begin{array}{c}43 \\
(\mathrm{~S}-\mathrm{CPR} \\
4.1 \mathrm{ng} / \mathrm{mL}\end{array}$ & 24.7 & $<15$ months & $\begin{array}{c}\text { N.M. } \\
\text { (S-CPR } 3.8 \\
\text { ng/mL) } \\
{[5.6 \text { years }]}\end{array}$ & $\begin{array}{l}\text { TPO-Ab: }(-) \\
\text { Tg-Ab: }(-) \\
\text { TR-Ab: }(-)\end{array}$ & $\begin{array}{l}\text { Positivity for } \\
\text { rheumatoid factor }\end{array}$ & $\begin{array}{l}\text { Presen } \\
\mathrm{t} \text { case }\end{array}$ \\
\hline
\end{tabular}

All patients were diagnosed with diabetes mellitus without ketoacidosis following different durations of hyperglycemic symptoms, tested positive for glutamic acid decarboxylase autoantibodies (GADA), and started insulin therapy.

${ }^{a}$ Hyperglycemia symptoms included thirst, polyuria, and body weight loss.

${ }^{\mathrm{b}} \mathrm{HbAlc}(\%)$ was estimated to be the National Glycohemoglobin Standardization Program (NGSP) equivalent value (\%) calculated using the formula HbAlc $(\%)=\mathrm{HbAlc}(\mathrm{Japan}$

Diabetes Society, JDS) (\%) $+0.4 \%$, based on HbAlc (JDS) (\%) expression measured using a Japanese standard substance (6).

${ }^{\mathrm{c}}$ The time periods between the diagnosis of diabetes mellitus and the measurement of urinary C-peptide (U-CPR) excretion are shown in square brackets.

${ }^{\mathrm{d}}$ Thyroid peroxidase antibody (TPO-Ab), thyroglobulin antibody (Tg-Ab), and thyroid-stimulating hormone receptor antibody (TR-Ab).

${ }^{\text {e}}$ Whether the case 2 patient exhibited Sjögren's syndrome was not reported. The present patient (Case 3) did not exhibited rheumatoid arthritis.

ANA: anti-nuclear antibody, N/A: not available, N.M.: not measured, HLA: human leukocyte antigen, S-CPR: serum C-peptide

rheumatoid factor remained positive $(32 \mathrm{IU} / \mathrm{mL})$, but she still had no clinical or laboratory findings of rheumatoid arthritis. The patient continued insulin therapy without complications and was in an insulin-independent state at the time of this writing.

\section{Discussion}

The adult Japanese woman of the present case was diagnosed with diabetes mellitus without ketoacidosis in the presence of high serum GADA titers following 6 weeks of hyperglycemic symptoms. After glucotoxicity improved upon the amelioration of the patient's hyperglycemia, her postprandial serum C-peptide level was found to be preserved. Her endogenous insulin secretion capacity remained almost unchanged after more than 5 years of insulin therapy. During that time, her GADA titers rapidly normalized.

Table 3 summarizes the reported patients who developed diabetes mellitus in the presence of transient GADA positivity and remained in an insulin-independent state. There are no apparent trends in age, sex, HLA-DR, HLA-DQ, or GADA titers. In all patients, the GADA titers normalized within 2 years, during which time there was no evident progression of endogenous insulin deficiency. The endogenous insulin secretion capacity of our patient showed little change over a period of more than 5 years. 
GADA is a useful marker of the autoimmune destruction of pancreatic beta cells in patients with T1D (3). However, GADA can also be detected in patients with other disorders, including type 2 diabetes mellitus (T2D) and rare GADArelated neurological diseases such as stiff-person syndrome; it can even be detected in healthy individuals (7). Our diabetic patient had none of the characteristic neurological manifestations of stiff-person syndrome, such as progressive rigidity or muscle spasm. T2D may occur in association with obesity. Our patient had no history of obesity and experienced a pathological BW loss during the hyperglycemic period before she was diagnosed with diabetes mellitus. After the correction of hyperglycemia, her BW did not increase, and decreased further during the prolonged diabetes management with an adequate diet and insulin therapy (Table 2). This finding suggests the improvement of slight excess of BW upon the changing of her eating habits. Her preexisting dyslipidemia, hypertension, and high-normal fasting plasma glucose level were also suggestive of the subsequent development of T2D. She was also found to have the HLA$\mathrm{A} * 24, \mathrm{DRB} 1 * 09: 01$, and DQB1*03:03 genes, which increase the susceptibility of Japanese individuals to T1D $(8,9)$. These findings indicate the presence of both clinical features of T2D and a genetic predisposition to T1D. Our patent likely developed T2D and also exhibited an autoimmune beta-cell destruction that terminated without progression to insulin deficiency. The appearance of GADA might have reflected a transient pancreatic autoimmune process.

The precise mechanism of the transient appearance of GADA in our patient remains unclear. However, studies have suggested that glucotoxicity induces the production of pancreatic beta-cell immunogens and accelerates the autoimmune processes in individuals who are genetically predisposed to pancreatic autoimmunity (10). Our patient consumed a certain amount of orange juice daily during 6 weeks of hyperglycemic symptoms and exhibited severe hyperglycemia before the management of her diabetes mellitus. Thus, soft-drink-aggravated hyperglycemia may have transiently induced pancreatic autoimmunity by causing severe glucotoxicity, which contributed to the appearance of her GADA.

Slowly progressive T1D is a subtype of T1D in Japan that is characterized by late-onset diabetes mellitus without ketoacidosis, slowly progressing beta-cell destruction, a clinical condition similar to that of $\mathrm{T} 2 \mathrm{D}$, and the presence of islet-related autoantibodies $(11,12)$. In patients with this disorder, GADA typically persists for an extended period of time and seldom disappears in the presence of preserved insulin secretion (13). Our patient's GADA disappeared rapidly. In addition, she tested negative for IA-2 antibody, IAA, ICA, and Zn-8 antibody, and her insulin secretion capacity was preserved 5 years after she developed diabetes mellitus (Table 2). Therefore, it is unlikely that our patient developed slowly progressive T1D.

Polyglandular autoimmune syndrome (PGAS) is a group of endocrine or nonendocrine organ-specific autoimmune disorders (14). Our patient presented with the brief appearance of GADA but developed neither typical T1D nor any other organ-specific disorders, including disorders involving the thyroid and adrenal glands, during her clinical course, which lasted for more than 5 years. In addition, although the patient showed rheumatoid factor positivity, an autoantibody against the Fc portion of immunoglobulin G (15), she did not develop any collagen diseases, including rheumatoid arthritis (16). Therefore, our patient was considered to be unaffected by PGAS. The coexistence of GADA and rheumatoid factor was likely to have been a simple coincidence.

In conclusion, our patient developed diabetes mellitus with the transient appearance of GADA and showed preserved endogenous insulin secretion capacity after more than 5 years of insulin therapy. The transient positivity for GADA likely reflected autoimmune beta-cell destruction that terminated without progressing to insulin deficiency. Although the precise mechanism remains unclear, this case provides insights into the pathophysiology of diabetes mellitus.

\section{The authors state that they have no Conflict of Interest (COI).}

\section{Acknowledgement}

We thank the medical laboratory technicians of Nagaoka Red Cross Hospital for their helpful technical support.

\section{References}

1. Seino Y, Nanjo K, Tajima N, et al; Committee of the Japan Diabetes Society on the Diagnostic Criteria of Diabetes Mellitus. Report of the committee on the classification and diagnostic criteria of diabetes mellitus. J Diabetes Investig 1: 212-228, 2010.

2. American Diabetes Association. Diagnosis and classification of diabetes mellitus. Diabetes Care 37 (Suppl 1): S81-S90, 2014.

3. Winter WE, Schatz DA. Autoimmune markers in diabetes. Clin Chem 57: 168-175, 2011.

4. Niregi E, Nagasaka S, Tomizawa Y, et al. A case of diabetes mellitus, in whom anti-GAD antibody turned into negative within 2 years of period, remaining still non-insulin dependent. Tonyobyo (J Jpn Diab Soc) 49: 717-721, 2006 (in Japanese).

5. Wada M, Nishiki M. Slowly progressive type 1 diabetes mellitus showing negative conversion of anti-glutamic acid decarboxylase antibody within 10 months in an elderly patient. Shimane Igaku (J Shimane M A) 27: 303-307, 2007 (In Japanese).

6. Committee on the Standardization of Diabetes Mellitus-Related Laboratory Testing of Japan Diabetes Society. International clinical harmonization of glycated hemoglobin in Japan: From Japan Diabetes Society to National Glycohemoglobin Standardization Program values. J Diabetes Invest 3: 39-40, 2012.

7. Kawasaki E. Type 1 diabetes and autoimmunity. Clin Pediatr Endocrinol 23: 99-105, 2014.

8. Nakanishi K, Kobayashi T, Murase T, et al. Association of HLAA24 with complete beta-cell destruction in IDDM. Diabetes 42: 1086-1093, 1993.

9. Committee on Type 1 Diabetes, Japan Diabetes Society. Differential association of HLA with three subtypes of type 1 diabetes: fulminant, slowly progressive and acute-onset. Diabetologia 52: 2513-2521, 2009.

10. Wilkin TJ. The accelerator hypothesis: weight gain as the missing link between Type I and Type II diabetes. Diabetologia 44: 914- 
922, 2001.

11. Committee of the Japan Diabetes Society on Type 1 Diabetes. Diagnostic criteria for slowly progressive insulin-dependent (type 1) diabetes mellitus (SPDDIM) (2012): Report by the Committee on Slowly Progressive Insulin-dependent (Type 1) Diabetes Mellitus of the Japan Diabetes Society. Tonyobyo (J Jpn Diab Soc) 56: 590-597, 2013 (in Japanese, Abstract in English).

12. Naik RG, Brooks-Worrell BM, Palmer JP. Latent autoimmune diabetes in adults. J Clin Endocrinol Metab 94: 4635-4644, 2009.

13. Kobayashi T, Nakanishi K, Okubo M, Murase T, Kosaka K. GAD antibodies seldom disappear in slowly progressive IDDM. Diabetes Care 19: 1031, 1996.

14. Cutolo M. Autoimmune polyendocrine syndromes. Autoimmun Rev 13: 85-89, 2014.

15. Ingegnoli F, Castelli R, Gualtierotti R. Rheumatoid factors: clinical applications. Dis Markers 35: 727-734, 2013.

16. Kay J, Upchurch KS. ACR/EULAR 2010 rheumatoid arthritis classification criteria. Rheumatology (Oxford) 51 (Suppl 6): vi5vi9, 2012.

(C) 2016 The Japanese Society of Internal Medicine http://www.naika.or.jp/imonline/index.html 